\title{
HUBUNGAN DUKUNGAN SOSIAL DAN NON SOSIAL DENGAN MOTIVASI BELAJAR PADA PESERTA UKMPPD
}

\author{
Intan Putri Permata Hati ${ }^{1}$, Hetti Rusmini ${ }^{2}$, Vira Sandayanti ${ }^{3}$, \\ 1,2Program Studi Kedokteran Fakultas Kedokteran Universitas Malahayati. Email: \\ intansaputri_p@yahoo.co.id \\ ${ }^{3}$ Program Studi Psikologi Fakultas Kedokteran Universitas Malahayati
}

\section{ABSTRACT: RELATIONSHIP BETWEEN SOCIAL AND NON-SOCIAL SUPPORT WITH LEARNING MOTIVATION IN PARTICIPANTS OF UKMPPD}

Students who have completed the Physician Professional Education stage are required to take the Medical Doctor Profession Program Student Competency Test (UKMPPD). This study aims to determine the relationship between social and non-social support and learning motivation among UKMPPD's participant students. This research is an analytical study with a cross sectional design. The research sample consisted of 170 UKMPPD participants for the November 2019 period at Malahayati University. Data collected using a social support scale, non-social support scale \& learning motivation scale. Data were analyzed using Spearman's Rank. The results showed that there was a significant relationship between social and non-social support and learning motivation among UKMPPD participants for the November 2019 period at Malahayati University.

\section{Keywords: learning motivation, social support, non social support, UKMPPD}

Mahasiswa yang telah menyelesaikan tahap Pendidikan Profesi Dokter wajib mengikuti Uji Kompetensi Mahasiswa Program Profesi Dokter (UKMPPD). Penelitian ini bertujuan untuk mengetahui hubungan antara dukungan sosial dan non sosial dengan motivasi belajar pada mahasiswa peserta UKMPPD. Penelitian ini merupakan penelitian analitik dengan desain cross sectional. Sampel penelitian berjumlah 170 peserta UKMPPD periode November Tahun 2019 di Universitas Malahayati. Pengambilan data menggunakan skala dukungan sosial, skala dukungan non sosial \& skala motivasi belajar. Data dianalisis menggunakan Rank Spearman's. Hasil penelitian menunjukkan adanya hubungan yang signifikan antara dukungan sosial dan non sosial dengan motivasi belajar pada mahasiswa peserta UKMPPD periode November tahun 2019 di Universitas Malahayati.

Kata Kunci: motivasi belajar, dukungan sosial, dukungan non sosial, UKMPPD

\section{PENDAHULUAN}

Mahasiswa yang telah menyelesaikan

tahap Pendidikan Profesi Dokter wajib mengikuti

Uji Kompetensi Mahasiswa Program Profesi

Dokter (UKMPPD). Uji Kompetensi Mahasiswa

Program Profesi Dokter (UKMPPD) terdiri dari dua ujian yaitu CBT (Computer based test) dan OSCE (Objective Structure Clinical Examination). Saat ini, angka ketidaklulusan UKMPPD masih tergolong tinggi terutama untuk ujian CBT. Berdasarkan data dari Panitia
Nasional UKMPPD, sejak bulan Agustus 2014 hingga bulan Mei 2018, UKMPPD telah meluluskan sekitar 39.000 dokter, dan menyisakan sekitar 2400 retaker (kurang dari 8 $\%$ dari total peserta yang telah mengikuti UKMPPD). Di Fakultas Kedokteran Universitas Islam Malang (FK UNISMA), angka kelulusan ujian CBT UKMPPD mulai tahun 2016 sampai 2018 rata-rata $71,1 \%$ per tahunnya. Hal ini masih jauh dari target angka kelulusan sebesar 80\% pada tahun 2020 (Tridelya, 2019). 


\section{HUBUNGAN DUKUNGAN SOSIAL DAN NON SOSIAL DENGAN MOTIVASI BELAJAR PADA PESERTA UKMPPD}

\begin{abstract}
Ada beberapa faktor yang mempengaruhi kesuksesan indivdiu dalam memperoleh hasil ujian yang baik. Menurut
\end{abstract} Slameto dalam Tridelya (2019) faktor-faktor yang mempengaruhi hasil ujian antara lain faktor internal yaitu : faktor jasmaniah, faktor psikologis (intelegensi, perhatian, minat dan bakat, motivasi, kematangan dan kesiapan belajar), faktor kelelahan jasmani dan rohani dan faktor eksternal yaitu : faktor keluarga, faktor pendidikan, serta faktor masyarakat. Dari beberapa faktor tersebut, motivasi merupakan salah satu faktor yang mempengaruhi hasil ujian. Menurut Wouters, Croiset, Galindo-Garre, \& Kusurkar (2016) motivasi sendiri terbukti memiliki hubungan dengan performa akademik dan yang dapat berdampak pada hasil kelulusan mahasiswa. Semakin tinggi motivasi mahasiswa dalam menghadapi ujian maka semakin tinggi juga peluang dalam keberhasilan belajar yang dihasilkan.

Motivasi menurut Mc. Donald (Am, 2011) didefinisikan sebagai perubahan energi dalam diri seseorang yang ditandai dengan munculnya "feeling" dan didahului dengan tanggapan terhadap adanya tujuan. Seseorang yang tidak mempunyai motivasi dalam belajar tak akan mungkin melakukan aktivitas belajar (Sriyanti, 2013).

Motivasi seseorang dapat timbul dan tumbuh berkembang melalui dirinya sendiri (intrinsik) yang bermakna sebagai keinginan dari diri sendiri untuk bertindak tanpa adanya rangsangan dari luar. Sedangkan motivasi ektrinsik di jabarkan sebagai motivasi datang dari luar individu atau lingkungan (Tasripiyah, 2012). Faktor-faktor yang mempengaruhi motivasi ekstrinsik antara lain meliputi faktor non sosial (lingkungan, fasilitas, media) dan dukungan sosial (Taylor, 2006).

Menurut Sarafino dalam Toding, David, dan Pali (2015), dukungan yang diterima oleh seseorang dari orang lain dapat disebut dengan dukungan sosial. Dukungan sosial ini dapat berupa dukungan emosional, dukungan penghargaan atau harga diri, dukungan instrumental, dukungan informasi atau dukungan dari kelompok. Dukungan sosial didefinisikan sebagai adanya orang-orang yang memperhatikan, menghargai, dan mencintai. Dukungan sosial merupakan kenyamanan psikis dan emosional yang diberikan kepada individu oleh keluarga, teman, rekan, dan yang lainnya, dapat juga berupa pertukaran interpersonal dimana salah seorang memberikan bantuan atau pertolongan kepada yang lain. Dukungan sosial memiliki beberapa komponen-komponen, antara lain: dukungan emosional (Emosional Support), dukungan penghargaan (Esteem support), dukungan instrumental (Tangible or instrumental support), dukungan informasi (Informational support).

Dengan adanya hal tersebut yang melatar belakangi, penelitian ini bertujuan untuk

Intan Putri Permata Hati, Program Studi Kedokteran Fakultas Kedokteran Universitas Malahayati. Email: intansaputrip@@yahoo.co.id

Vira Sandayanti, Program Studi Psikologi Fakultas Kedokteran Universitas Malahayati.

Hetti Rusmini, Program Studi Kedokteran Fakultas Kedokteran Universitas Malahayati. 


\section{HUBUNGAN DUKUNGAN SOSIAL DAN NON SOSIAL DENGAN MOTIVASI BELAJAR PADA PESERTA UKMPPD}

mengetahui apakah ada hubungan dukungan sosialdengan motivasi belajar pada peserta UKMPPD periode November tahun 2019 di Universitas Malahayati.

\section{METODE}

Penelitian ini menggunakan jenis penelitian kuantitatif dan metode penelitian analitik dengan pendekatan cross sectional. Peneliti mengambil sampel peserta UKMPPD periode November tahun 2019 yang akan mengikuti ujian UKMPPD di Universitas Malahayati dengan populasi berjumlah 250 peserta. Besar sampel dalam penelitian ini ditentukan dengan menggunakan rumus Issac and Michael, sehingga besar sampel yang diperoleh 170 sampel. Metode yang digunakan dalam penelitian ini adalah simpel random sampling.

Penelitian ini menggunakan skala dukungan sosial yang terdiridari 44 pernyataan, skala dukungan non sosial 23 pernyataan dan skala motivasi belajar 36 pernyataan pilihan jawaban menggunakan skor skala likert dan pilihan jawaban: sangat setuju, setuju, kurang setuju, tidak setuju dan sangat tidak setuju. Pengolahan data dilakukan dengan program komputer SPSS versi 21 dan menggunakan teknik analisis korelasi Spearman Rank.

HASIL

Berdasarkan penelitian yang dilakukan dengan menyebarkan skala dukungan sosial dan non sosial dengan motivasi belajar di Universitas Malahayati pada peserta UKMPPD periode November tahun 2019 pada bulan November didapatkan 170 responden yang memenuhi kriteria penelitian, didapatkan hasil sebagai berikut:

Tabel 1

Distribusi Frekuensi Karakteristik Responden

\begin{tabular}{lll}
\hline & $\mathbf{F}$ & $\%$ \\
\hline Jenis Kelamin & & \\
\hline Laki-laki & 39 & 22.9 \\
Perempuan & 131 & 77.1 \\
\hline Usia & & \\
\hline $21-30$ & 168 & 98.82 \\
$>31$ & 2 & 1.18 \\
\hline
\end{tabular}

Berdasarkan tabel 1, diketahui bahwa sebagian besar responden berjenis kelamin perempuan

(77.1\%) dan berusia $21-30$ tahun (98.82\%).

Intan Putri Permata Hati, Program Studi Kedokteran Fakultas Kedokteran Universitas Malahayati. Email: intansaputri p@yahoo.co.id

Vira Sandayanti, Program Studi Psikologi Fakultas Kedokteran Universitas Malahayati.

Hetti Rusmini, Program Studi Kedokteran Fakultas Kedokteran Universitas Malahayati. 


\section{HUBUNGAN DUKUNGAN SOSIAL DAN NON SOSIAL DENGAN MOTIVASI BELAJAR PADA PESERTA UKMPPD}

Tabel 2

Distribusi Frekuensi Dukungan Sosial

\begin{tabular}{ccc}
\hline Tingkat Dukungan Sosial & $F$ & $\%$ \\
\hline Rendah & 83 & 48.8 \\
Tinggi & 87 & 51.2 \\
\hline Total & 170 & 100 \\
\hline
\end{tabular}

Tabel 3

Persentase Jawaban Item Skala Dukungan Sosial

\begin{tabular}{clccc}
\hline Noltem & \multicolumn{1}{c}{ PERNYATAAN } & SKOR & $\%$ \\
\hline \multicolumn{1}{c}{ 3 ltem Dengan Skor Tertinggi } & & \\
\hline 4 & $\begin{array}{l}\text { Orang tua menunjukkan kasih sayang yang lebih terutama ketika responden } \\
\text { sedang menghadapi masalah }\end{array}$ & 733 & 86.2 \\
35 & $\begin{array}{l}\text { Orang tua selalu memberikan uang saku untuk membeli keperluan yang } \\
\text { responden butuhkan }\end{array}$ & 732 & 86.1 \\
28 & $\begin{array}{l}\text { Nasehat yang diberikan orang tua membantu responden dalam } \\
\text { menyelesaikan masalah }\end{array}$ & 725 & 85.3 \\
\hline 3 & $\begin{array}{l}\text { Responden merasa teman-teman tidak peka dengan perasaan saya } \\
\text { Responden merasa tidak nyaman menceritakan masalah pribadi kepada } \\
\text { teman }\end{array}$ & 460 & 57.4 \\
29 & $\begin{array}{l}\text { Responden tidak selalu dipermudah setiap akan berkonsultasi masalah } \\
\text { akademik dengan dosen pembimbing. }\end{array}$ & 390 & 45.9 \\
\hline & Berdasarkan tabel 2 diatas, dapat disimpulkan sebagian besar peserta UKMPPD memiliki
\end{tabular}

dukungan sosial tinggi (51.2\%). Lebih lanjut, berdasarkan tabel 3 diketahui 3 pernyataan dengan skor tertinggi dan 3 terendah dari skala dukungan sosial. Skor skala ini hasil penjumlahan dari 170 responden dengan skor maksimal per item 850. Pernyataandengan skor tertinggi menggambarkan responden merasa mendapat dukungan sosial, yaitu item nomor 4 dengan skor $733(86.2 \%)$ orang tua menunjukkan kasih sayang ketika responden sedang mengalami masalah, item nomor 35 dengan skor 732 (86.1\%) orang tua selalu memberikan uang saku untuk membeli keperluan yang dibutuhkan, item 28 dengan skor $725(85.3 \%)$ Nasehat yang diberikan orang tua membantu dalam menyelesaikan masalah.

Pernyataan dengan skor terendah menggambarkan responden kurang mendapatkan dukungan sosial yang di gambarkan melalui pernyataan berikut yaitu pada item nomor 29 dengan skor paling rendah $390(45.9 \%)$ responden dipermudah setiap akan berkonsultasi masalah akademik dengan dosen pembimbing, skor rendah nomo 2 yaitu item nomor 5 dengan skor 460 (54.1\%) responden merasa nyaman menceritakan masalah pribadi kepada teman, terakhir item nomor 3 dengan skor $488(57.4 \%)$ teman-teman peka terhadap perasaan responden.

Intan Putri Permata Hati, Program Studi Kedokteran Fakultas Kedokteran Universitas Malahayati. Email: intansaputri p@yahoo.co.id

Vira Sandayanti, Program Studi Psikologi Fakultas Kedokteran Universitas Malahayati.

Hetti Rusmini, Program Studi Kedokteran Fakultas Kedokteran Universitas Malahayati. 


\section{HUBUNGAN DUKUNGAN SOSIAL DAN NON SOSIAL DENGAN MOTIVASI BELAJAR PADA PESERTA UKMPPD}

Tabel 4

Distribusi Frekuensi Dukungan Non-sosial

\begin{tabular}{ccc}
\hline Tingkat Dukungan Non Sosial & $F$ & $\%$ \\
\hline Rendah & 60 & 35.3 \\
Tinggi & 110 & 64.7 \\
\hline Total & 170 & 100 \\
\hline
\end{tabular}

Tabel 5

Distribusi Frekuensi Aspek Skala Dukungan Non Sosial

\begin{tabular}{rlcc}
\hline \multirow{2}{*}{ No } & \multicolumn{2}{c}{ Aspek- Aspek Dukungan Non Sosial } & \multicolumn{2}{c}{ Total Skor Aspek } \\
\cline { 3 - 4 } & & $\mathrm{N}$ & $\%$ \\
\hline 1 & Waktu Belajar & 691,5 & $81,3 \%$ \\
2 & Sarana dan Prasarana & 665,6 & $78,3 \%$ \\
3 & Udara Tempat Belajar & 636,6 & $74,3 \%$ \\
4 & Kebisingan Tempat & 598,3 & $70,3 \%$ \\
\hline
\end{tabular}

Berdasarkan hasil analisis data tabel 4, diketahui bahwa sebagian besar responden memiliki dukungan non sosial dalam kategori tinggi (64.7\%). Lebih lanjut, bedasarkan tabel 5 didapatkan bahwa sebagian besar responden sudah memperoleh dukungan non sosial dalam aspek waktu belajar (81.3\%).

Tabel 6

Distribusi Frekuensi Motivasi Belajar

\begin{tabular}{ccc}
\hline Tingkat Motivasi Belajar & F & $\%$ \\
\hline Rendah & 0 & 0 \\
Sedang & 63 & 37.1 \\
Tinggi & 107 & 62.9 \\
\hline Total & 170 & $100.0 \%$ \\
\hline
\end{tabular}

Tabel 7

Distribusi Frekuensi Skala Motivasi Belajar

\begin{tabular}{clcc}
\hline Noltem & \multicolumn{1}{c}{ PERNYATAAN } & SKOR & $\%$ \\
\hline & \multicolumn{1}{c}{ 3 Item Dengan Skor Tertinggi } & & \\
\hline 6 & Mengikuti bimbingan didalam ruangan hingga bimbingan selesai & 748 & 88,0 \\
5 & Berusaha hadir setiap hari untuk belajar & 740 & 87.1 \\
1 & Berusaha hadir tepat waktu untuk mengikuti bimbingan belajar. & 737 & 86.7 \\
& 3 Item Dengan Skor Terendah & 500 & 58.8 \\
15 & Menunda jika ingin belajar kembali di rumah & 507 & 59.6 \\
17 & Tidak senang dengan bimbingan, jika materi bimbingansulit untuk dimengerti & 511 & 60.1 \\
36 & Senang mengobrol jika ada jam pelajaran kosong & & \\
\hline
\end{tabular}

Intan Putri Permata Hati, Program Studi Kedokteran Fakultas Kedokteran Universitas Malahayati. Email: intansaputri_p@yahoo.co.id

Vira Sandayanti, Program Studi Psikologi Fakultas Kedokteran Universitas Malahayati.

Hetti Rusmini, Program Studi Kedokteran Fakultas Kedokteran Universitas Malahayati. 


\section{HUBUNGAN DUKUNGAN SOSIAL DAN NON SOSIAL DENGAN MOTIVASI BELAJAR PADA PESERTA UKMPPD}

Berdasarkan analisis data tabel 6, dapat disimpulkan bahwa sebagian besar peserta UKMPPD memiliki motivasi belajar tinggi (62.9\%). Lebih lanjut, bedasarkan tabel 7 didapatkan hasil distribusi frekuensi skala dukungan non sosial, yaitu 3 pernyataan dengan skor tertinggi dan 3 terendah. Pernyataandengan skor tertinggi menggambarkan responden mempunyai motivasi belajar yang tinggi, yaitu item nomor 6 dengan skor 748 (88\%) Saya mengikuti bimbingan didalam ruangan hingga bimbingan selesai, item nomor 5 dengan skor $740(87,1 \%)$ responden berusaha hadir setiap hari untuk belajar, item nomor 1dengan skor $737(86,7 \%)$ responden berusaha hadir tepat waktu untuk mengikuti bimbingan belajar. Pernyataan dengan skor terendah menggambarkan responden kurang mempunyai motivasi belajar yaitu item nomor 15 dengan skor $500(58,8 \%)$ sering menunda jika ingin belajar kembali di rumah, item nomor 17 dengan skor 507 (59,6\%) responden tidak senang bimbingan, jika materi bimbingannya sulit untuk dimengerti, item nomor 36 dengan skor $511(60,1 \%)$ responden tidak senang bimbingan, jika materi bimbingannya sulit untuk dimengerti.

Tabel 8

Korelasi Dukungan Sosial dan Non-Sosial dengan Motivasi Belajar

\begin{tabular}{ll}
\hline Skor motivasi belajar \\
\hline Dukungan Sosial & $r=.323^{\star *}$ \\
\hline Dukungan Non-sosial & $r=.198^{* *}$
\end{tabular}
${ }^{\star \star} p<.01$

Berdasarkan hasil analisis data pada tabel 8 dapat disimpulkan bahwa terdapat hubungan positif signifikan antara dukungan sosial dan non sosial dengan motivasi belajar pada peserta UKMPPD. Hal ini menunjukkan bahwa semakin tinggi dukungan sosial dan non sosial yang didapat maka semakin tinggi tingkat motivasi belajar pada peserta UKMPPD, begitu juga sebaliknya semakin rendah tingkat dukungan sosial dan non sosial maka semakin rendah tingkat motivasi belajar.

DISKUSI

Hasil penelitian menemukan bahwa sebagian besar responden memiliki dukungan sosial yang tinggi. Myers menyatakan bahwa faktor yang mendorong seseorang memberikan dukungan sosial yang positif karena ada rasa empati, yaitu turut merasakan kesusahan orang lain dengan tujuan mengantisipasi emosi dan motivasi tingkah laku untuk mengurangi kesusahan dan meningkatkan kesejahteraan orang lain, kemudian karena adanya norma dan nilai sosial yang berguna untuk membimbing individu untuk menjalankan kewajiban dalam kehidupan, yang terakhir karena adanya

Intan Putri Permata Hati, Program Studi Kedokteran Fakultas Kedokteran Universitas Malahayati. Email: intansaputri p@yahoo.co.id

Vira Sandayanti, Program Studi Psikologi Fakultas Kedokteran Universitas Malahayati.

Hetti Rusmini, Program Studi Kedokteran Fakultas Kedokteran Universitas Malahayati. 


\section{HUBUNGAN DUKUNGAN SOSIAL DAN NON SOSIAL DENGAN MOTIVASI BELAJAR PADA PESERTA UKMPPD}

pertukaran sosial yaitu hubungan timbal balik perilaku sosial antara cinta, pelayanan, dan informasi (Kurniawati, Faizah, \& Rahma, 2018). Menurut Gottlieb dukungan sosial terdiri dari informasi atau nasihat verbal dan nonverbal, bantuan nyata atau tindakan yang diberikan oleh adanya keakraban sosial yang didapat karena kehadiran orang lain atau kelompok dan mempunyai manfaat emosional atau berupa efek perilaku bagi pihak penerima, dalam hal ini efeknya berupa semangat atau motivasi belajar (Fajriyah, Abdullah, \& Amrullah, 2016)

Dalam penelitian Maslihah (2011) didapatkan hasil dukungan sosial berpengaruh secara signifikan terhadap prestasi akademik. Penelitian ini menunjukkan bahwa semakin besar dukungan sosial baik bentuk emotional support maupun instrumental support, maka semakin besar pula prestasi akademik yang dicapai siswa. Demikian sebaliknya, tanpa kehadiran dukungan sosial, maka prestasi akademikpun akan semakin menurun. Adanya dukungan sosial orang tua saat siswa menghadapi kesulitan atau membutuhkan bantuan terutama kesulitan berkaitan dengan sekolah memiliki hubungan yang signifikan dengan pencapaian prestasi akademik siswa. Dengan kata lain, siswa tidak cukup mendapat dukungan yang bersifat emosional atau psikhis tetapi dukungan sosial atau responsivitas orang tua dalam bentuk bantuan, nasihat ataupun bimbingan langsung saat ia menghadapi kesulitan terutama kesulitan yang berkaitan dengan pendidikan atau sekolah memberikan dampak yang cukup besar bagi siswa terutama bagi pencapaian prestasi akademik siswa.

Lebih lanjut, hasil penelitian ini menunjukkan bahwa sebagian besar peserta UKMPPD memiliki motivasi belajar tinggi. Motivasi belajar adalah keseluruhan daya penggerak di dalam diri yang menimbulkan kegiatan belajar, yang menjamin kelangsungan dari kegiatan belajar dan memberi arah pada kegiatan belajar, sehingga tujuan yang dikehendaki itu dapat tercapai. Aspek-aspek motivasi belajar antara lain ketekunan dalam belajar, ulet dalam menghadapi kesulitan, minat dan ketajaman perhatian dalam belajar, berprestasi dalam belajar, dan mandiri dalam belajar (Am, 2011).

Motivasi belajar merupakan
keseluruhan daya penggerak dalam diri mahasiswa yang menimbulkan kegiatan belajar yang menjamin kelangsungan dari kegiatan belajar dan yang memberikan arah pada kegiatan belajar, sehingga tujuan yang dikehendaki oleh mahasiswa dapat tercapai. Motivasi belajar memegang peranan yang penting dalam naik dan turunnya prestasi belajar (Dhitaningrum, 2013). Seseorang akan memiliki motivasi belajar yang tinggi bila ia menyadari dan memahami tujuan yang akan dicapainya. Bila seseorang memahami citacitanya secara baik, maka ia akan terdorong

Intan Putri Permata Hati, Program Studi Kedokteran Fakultas Kedokteran Universitas Malahayati. Email: intansaputri p@yahoo.co.id

Vira Sandayanti, Program Studi Psikologi Fakultas Kedokteran Universitas Malahayati.

Hetti Rusmini, Program Studi Kedokteran Fakultas Kedokteran Universitas Malahayati. 


\section{HUBUNGAN DUKUNGAN SOSIAL DAN NON SOSIAL DENGAN MOTIVASI BELAJAR PADA PESERTA UKMPPD}

untuk semakin giat belajar (Suciani \& Safitri, 2014). Prawira (2012) menyatakan motivasi belajar adalah segala sesuatu yang ditunjukkan untuk mendorong atau memberikan semangat kepada seseorang yang melakukan kegiatan belajar agar menjadi lebih giat lagi dalam belajarnya untuk memperoleh prestasi yang lebih baik lagi. Menurut Wouters, Croiset, Galindo-Garre, \& Kusurkar (2016) motivasi sendiri terbukti memiliki hubungan dengan performa akademik dan yang dapat berdampak pada hasil kelulusan mahasiswa.Semakin tinggi motivasi mahasiswa dalam menghadapi ujian maka semakin tinggu juga peluang dalam keberhasilan belajar yang dihasilkan.

Hal ini didukung oleh hasil penelitian Arifiana (dalam Tunggadewi \& Indriana, 2018) bahwa motivasi belajar merupakan hal penting demi terciptanya pembelajaran yang optimal. Penelitian oleh Lijun (2011) menyebutkan bahwa motivasi berhubungan positif dengan strategi dan pencapaian hasil belajar. Dan penelitian oleh Yu (2012) bahwa hubungan motivasi dan strategi belajar juga mendapatkan hasil yang positif. Hasil penelitian Hamdu dan Agustina (2011) disimpulkan bahwa motivasi belajar berpengaruh terhadap prestasi belajar. Selain itu, terdapat penelitian yang menunjukkan adanya hubungan motivasi belajar dan kesiapan belajar mandiri terhadap kelulusan UKMPPD. Putri (2018) di FK Universitas Lampung didapatkan tingkat motivasi belajar pada responden yangmengikuti Ujian CBT UKMPPD periode November 2017 adalah tinggi dan terdapat hubungan bermakna antara motivasi belajar terhadap kelulusan ujian CBT UKMPPD.

Hasil analisis korelasi menunjukkan adanya hubungan positif signifikan antara dukungan sosial dan non sosial dengan motivasi belajar pada peserta UKMPPD. Ahmed dalam Dhitaningrum (2013) menyatakan motivasi belajar dan kondisi emosi menjadi perantara pada pengaruhnya dukungan sosial terhadap prestasi belajar mahasiswa. Pernyataan tersebut dapat diartikan bahwa ketika mahasiswa tidak memperoleh dukungan sosial yang positif dalam belajarnya, maka hal ini akan mempengaruhi stabilitas emosi mahasiswa tersebut. Sehingga motivasi belajar mahasiswa mejadi terganggu dan berimbaskepada prestasi belajar mahasiswa tersebut. Sarafino dalam Suciani dan Safitri (2014) bahwa individu yang memiliki peran penting memiliki pengaruh terhadap peningkatan motivasi belajar bagi mahasiswa, dan dosen adalah salah satu orang yang memberi perananpenting dalam pencapaian prestasi belajarnya.

Hasil penelitian ini sesuai dengan penelitian serupa yang dilakukan oleh Suciani dan Safitri (2014) yang menunjukkan hasil penelitian dengan koefisien korelasi sebesar 0,694 dengan sig $0,000(p<0,05)$, artinya ada

Intan Putri Permata Hati, Program Studi Kedokteran Fakultas Kedokteran Universitas Malahayati. Email: intansaputri_p@yahoo.co.id

Vira Sandayanti, Program Studi Psikologi Fakultas Kedokteran Universitas Malahayati.

Hetti Rusmini, Program Studi Kedokteran Fakultas Kedokteran Universitas Malahayati. 


\section{HUBUNGAN DUKUNGAN SOSIAL DAN NON SOSIAL DENGAN MOTIVASI BELAJAR PADA PESERTA UKMPPD}

hubungan positif dan signifikan dukungan sosial dengan motivasi belajar pada mahasiswa Universitas Esa Unggul. Hasil penelitian Pramana dan Wilani (2018) juga menyatakan bahwa terdapat hubungan yang signifikan dan positif antara dukungan sosial dengan motivasi belajar dimana hasil penelitian menunjukkan bahwa semakin tinggi dukungan sosial yang didapat maka semakin tinggi tingkat motivasi belajar, begitu juga sebaliknya semakin rendah tingkat dukungan sosialmaka semakin rendah tingkat motivasi belajar.

Hasil penelitian yang dilakukan oleh Dhitaningrum (2013) diketahui hasil bahwa motivasi belajar mahasiswa timbul disebabkan adanya dukungan yang diberikan oleh dukungan sosial orang tua sehingga mahasiswa memiliki keinginan untuk berprestasi. Artinya mahasiswa merasa tidak sendiri, dihargai, merasa diperhatikan dan dicintai. Perasaanperasaan yang timbul membuat mahasiswa menjadi tidak mudah frustasi, optimis, memiliki energi yang positif, disiplin dan memiliki tujuan atau target dalam belajarnya, sehingga mahasiswa menjadi fokus dalam menjalankan tugas belajarnya.

Menurut Yusuf (dalam Rahmawati, 2016) motivasi belajar dapat timbul karena faktor eksternal. Salah satu faktor eksternal adalah faktor non-sosial, faktor non-sosial merupakan faktor yang berasal dari keadaan atau kondisi fisik di sekitar yang meliputi keadaan udara (cuaca panas atau dingin), waktu (pagi, siang, atau malam), tempat (sepi, bising, atau kualitas tempat belajar), dan fasilitas belajar (sarana dan prasarana).

Menurut Sunaryo dalam Indah (2017) faktor udara, cuaca, waktu, tempat dapat mempengaruhi proses belajar bagi individu yang dapat mempengaruhi kenyamanan peserta didik dalam belajar. Pada penelitian ini terdapat hubungan positif yang bermakna antara dukungan non-sosial dengan motivasi belajar pada peserta ujian UKMPPD periode November tahun 2019. Tanda positif tersebut menunjukkan bahwa semakin tinggi dukungan non-sosial yang didapat maka semakin tinggi tingkat motivasi belajar pada peserta UKMPPD, begitu juga sebaliknya semakin rendah tingkat dukungan non-sosialmaka semakin rendah tingkat motivasi belajar.

\section{SIMPULAN DAN SARAN}

Bedasarkan hasil penelitian dapat disimpulkan bahwa ada hubungan yang positif dan signifikan antara dukungan sosial dan non sosial dengan motivasi belajar pada peserta UKMPPD. Hasil Penelitian ini memberi implikasi pada pentingnya mengembangkan lingkungan sosial maupun lingkungan fisik yang memfasilitasi proses belajar mahasiswa agar motivasi meningkat dan pada akhirnya meningkatkan tingkat kelulusan UKMPPD. Untuk penelitian selanjutnya diharapkan dapat

Intan Putri Permata Hati, Program Studi Kedokteran Fakultas Kedokteran Universitas Malahayati. Email: intansaputri p@yahoo.co.id

Vira Sandayanti, Program Studi Psikologi Fakultas Kedokteran Universitas Malahayati.

Hetti Rusmini, Program Studi Kedokteran Fakultas Kedokteran Universitas Malahayati. 


\section{HUBUNGAN DUKUNGAN SOSIAL DAN NON SOSIAL DENGAN MOTIVASI BELAJAR PADA PESERTA UKMPPD}

memperluas sampel penelitian pada beberapa

periode pelaksanaan UKMPPD dan asal

universitas sehingga hasil penelitian yang

diperoleh lebih kaya dan representatif.

\section{DAFTAR PUSTAKA}

Am, S. (2011). Interaksi dan motivasi belajar mengajar. Jakarta: Raja Grafindo Persada.

Dhitaningrum, M. (2013). Hubungan antara persepsi mengenai dukungan sosial orang tua dengan motivasi belajar siswa SMA Negeri 1 Gondang Kabupaten Tulungagung. Character: Jurnal Penelitian Psikologi., 1(2).

Fajriyah, N. N., Abdullah, A., \& Amrullah, A. J. (2016). Dukungan Sosial Keluarga pada Pasien Hipertensi. Jurnal IImiah Kesehatan, 9(2), 97000.

Hamdu, G., \& Agustina, L. (2011). Pengaruh motivasi belajar siswa terhadap prestasi belajar IPA di sekolah dasar. Jurnal penelitian pendidikan, 12(1), 9096.

INDAH, S. N. (2017). HUBUNGAN PEMBIMBINGAN TERHADAP KELULUSAN UJIAN CBT UKMPPD NASIONAL MAHASISWA FAKULTAS KEDOKTERAN UNIVERSITAS LAMPUNG PERIODE AGUSTUS 2015-MEI 2016.

Kurniawati, Y., Faizah, F., \& Rahma, U. (2018). Dukungan Sosial Dan Empati Pada Siswa Berkebutuhan Khusus Berdasar Jenjang Sekolah Menengah Dan Perguruan Tinggi. Insight: Jurnal Pemikiran dan Penelitian Psikologi, 14(2), 189-200.
Lijun, Y. U. (2011). The investigation of learning motivation and strategy in the normal undergraduates. Cross-cultural communication, 7(3), 126-131.

Maslihah, S. (2011). Studi tentang hubungan dukungan sosial, penyesuaian sosial di lingkungan sekolah dan prestasi akademik siswa SMPIT Assyfa Boarding School Subang Jawa Barat. Jurnal Psikologi, 10(2), 103-114.

Pramana, A. G. K., \& Wilani, N. M. A. (2018). Hubungan Dukungan Sosial dengan Motivasi Belajar Siswa di SMA Negeri Bali Mandara. Jurnal Psikologi Udayana, 5(01), 189-196.

Prawira, P. A. (2012). Psikologi pendidikan dalam perspektif baru. Jogjakarta: ArRuzz Media, 159.

Putri YT. (2018). Hubungan motivasi belajar terhadap kelulusan ujian CBT UKMPPD mahasiswa fakultas kedokteran Universitas Lampung periode November 2017. Skripsi. Lampung: Universitas Lampung.

Rahmawati, R. (2016). Faktor-Faktor Yang Mempengaruhi Motivasi Belajar Siswa Kelas X Sma N 1 Piyungan Pada Mata Pelajaran Ekonomi Tahun Ajaran 2015/2016. Jurnal Pendidikan dan Ekonomi, 5(4), 326-336.

Sriyanti, L. (2013). Psikologi belajar. Yogyakarta: Ombak, 187.

Suciani, D., \& Safitri, S. (2014). Hubungan dukungan sosial dengan motivasi belajar pada mahasiswa Universitas Esa Unggul. Jurnal Psikologi Esa Unggul, 12(02), 126710.

Intan Putri Permata Hati, Program Studi Kedokteran Fakultas Kedokteran Universitas Malahayati. Email: intansaputrip@@yahoo.co.id

Vira Sandayanti, Program Studi Psikologi Fakultas Kedokteran Universitas Malahayati.

Hetti Rusmini, Program Studi Kedokteran Fakultas Kedokteran Universitas Malahayati. 


\section{HUBUNGAN DUKUNGAN SOSIAL DAN NON SOSIAL DENGAN MOTIVASI BELAJAR PADA PESERTA UKMPPD}

Tasripiyah, A. S. (2012). Hubungan Koping dan Dukungan Sosial dengan Body Image Pasien Kanker Payudara Post Mastektomi Di Poli Bedah Onkologi RSHS Bandung. Students e-Journal, 1(1), 33.

Taylor, S. E. (2006). Health psychology. Tata McGraw-Hill Education.

Toding, W. R., David, L., \& Pali, C. (2015). Hubungan dukungan sosial dengan motivasi berprestasi pada mahasiswa angkatan 2013 Fakultas Kedokteran Universitas Sam Ratulangi. eBiomedik, 3(1).

Tridellya, F. (2019). KORELASI MOTIVASI DAN KESIAPAN BELAJAR MANDIRI TERHADAP KELULUSAN COMPUTER BASED TEST UJI KOMPETENSI MAHASISWA PROGRAM PROFESI DOKTER UNIVERSITAS ISLAM MALANG. Jurnal Bio Komplementer Medicine, $6(3)$.

Tunggadewi, T. P., \& Indriana, Y. (2018). Hubungan antara dukungan sosial dengan motivasi belajar pada santri di Pesantren Tahfidz Daarul Qur'An Jawa Tengah. Empati, 6(3), 313-317.

Wouters, A., Croiset, G., Galindo-Garre, F., \& Kusurkar, R. A. (2016). Motivation of medical students: selection by motivation or motivation by selection. BMC medical education, 16(1), 1-9.

Yu, X. M. (2012). An empirical study on the correlation between English learning motivation and strategy. Asian Social Science, 8(8), 218-224.

Intan Putri Permata Hati, Program Studi Kedokteran Fakultas Kedokteran Universitas Malahayati. Email: intansaputri p@yahoo.co.id

Vira Sandayanti, Program Studi Psikologi Fakultas Kedokteran Universitas Malahayati. Hetti Rusmini, Program Studi Kedokteran Fakultas Kedokteran Universitas Malahayati. 